\title{
PERANCANGAN APLIKASI VIDEO STREAMING UNTUK PEMANTAUAN AIR LAUT KETIKA TERJADI GEMPA
}

\author{
Wahyu Irawan, Denny Dermawan, Nurcahyani Dewi \\ Jurusan Teknik Informatika \\ Sekolah Tinggi Teknologi Adisutjipto Yogyakarta \\ informatika@stta.ac.id
}

\begin{abstract}
The geographical position of Indonesia is located in an earthquake-prone area that is potentially most earthquake-tsunami, it takes a transmission medium to connect the camera monitoring results between the sender and receiver of information or data that may provide information to the natural disasters.

The transmission media can be a media streaming seawater and alarm monitoring that is connected with vibration sensor that functions as a medium for early warning of natural disasters. From the test results it can be concluded that the alarm system warning of earthquakes, able to work well as vibration sensor detects vibration. As well as video streaming process can run well on a LAN network using HTTP protocol 8080. Society as a client can access the video streaming server via the address specified by the application server.
\end{abstract}

Keywords: System monitoring, streaming, interface

\section{Latar Belakang}

Metode streaming merupakan metode yang memungkinkan pengguna dapat melihat informasi yang sama pada saat yang relatif sama ketika informasi dikirimkan oleh orang lain melalui perangkat mikrofon ataupun kamera. Metode ini sangat membantu untuk penyampaian informasi secara otomatis agar orang lain dapat mengetahui suatu informasi terkini walaupun berada di lain tempat. Oleh karena itu, untuk memberikan informasi kepada masyarakat secara streaming dibutuhkan alat pemantau air laut serta alarm yang terhubung dengan sensor getar yang berfungsi sebagai media peringatan dini bencana alam.

\section{Tinjauan Pustaka}

Dalam Edi Sukriansyah, Hubbul Walidainy, Nasaruddin (2012), dilakukan perncangan sistem monitoring menggunakan Wireless UHF Camera dan Wireless IP Camera sebagai media pengambil data berupa gambar yang akan dikirimkan kepada masyarakat sebagai media informasi 


\section{Dasar Teori}

\section{Streaming}

Streaming adalah sebuah teknologi untuk menjalankan file video atau audio secara langsung ataupun dengan pre-recorder dari sebuah mesin server (web server). Dengan kata lain, file video ataupun audio yang terletak dalam sebuah server dapat secara langsung dijalankan sesaat setelah ada permintaan dari user, sehingga proses running aplikasi yang diunduh berupa waktu yang lama dapat dihindari tanpa harus melakukan proses penyimpanan terlebih dahulu.

\section{ATMega8535}

Mikrokontroler merupakan pusat kerja dari suatu sistem elektronika seperti halnya mikroprosesor sebagai otak komputer dari sebuah perangkat komputer. Kelebihan bagi mikrokontroler adalah terdapatnya memori dan input port atau output dalam suatu kemasan Integrated Circuit (IC). Kemampuannya yang programmable, fitur yang lengkap seperti Analog to Digital Converter (ADC) internal, Electrically Erasable Programmable Read-Only Memory (EEPROM) internal, port I/O, komunikasi serial. Mikrokontroler digunakan diberbagai sistem elektronik, seperti pada robot, industri, sistem alarm, peralatan telekomunikasi, hingga sistem keamanan.

\section{Perancangan Sistem}

Blok Diagram Sistem

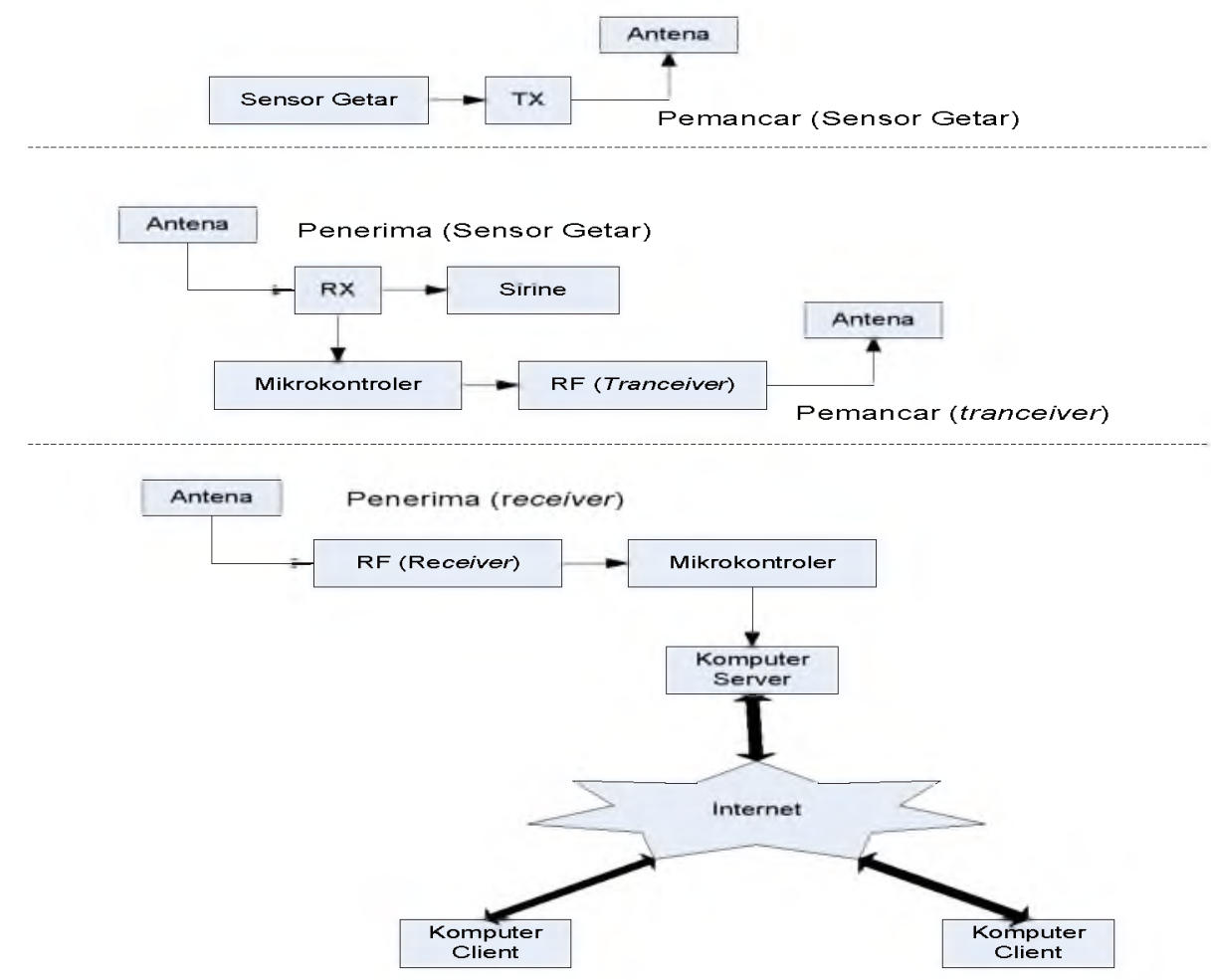

Gambar 1. Blok Diagram Sistem 


\section{Perancangan Aplikasi Server}

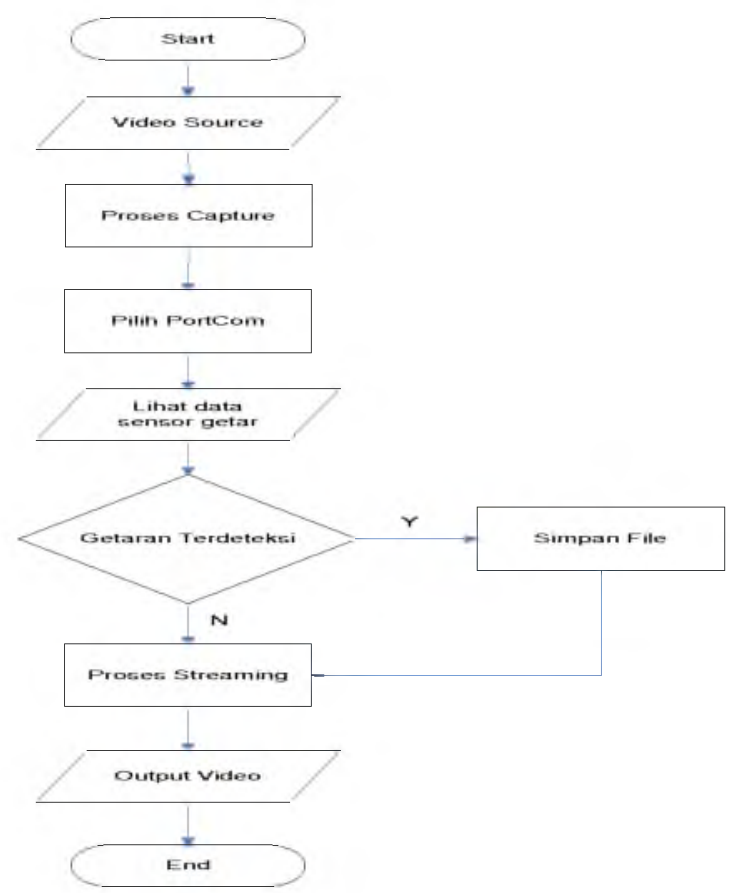

Gambar 2. Flowchart Aplikasi Server

\section{Perancangan Aplikasi Client}

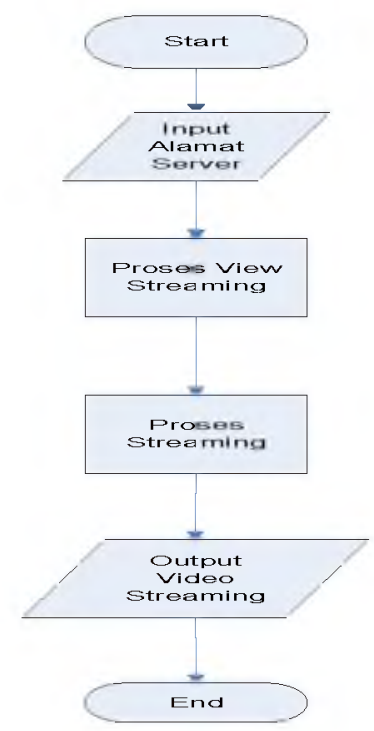

Gambar 3. Flowchart Aplikasi Client 


\section{Ujicoba}

\section{Uji coba Hardware}

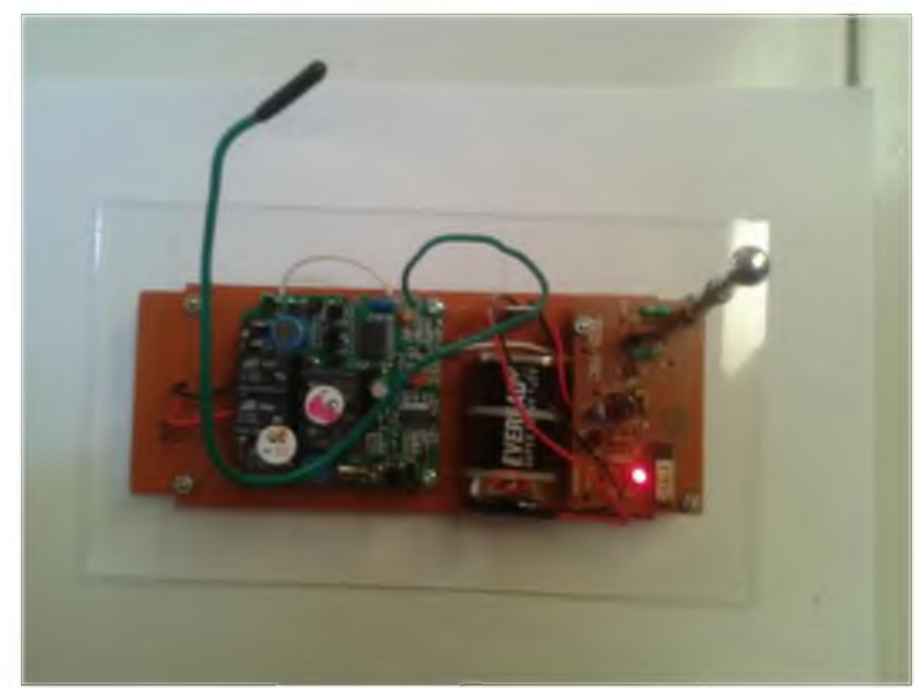

Gambar 4. Rangkaian sensor getar dan transceiver

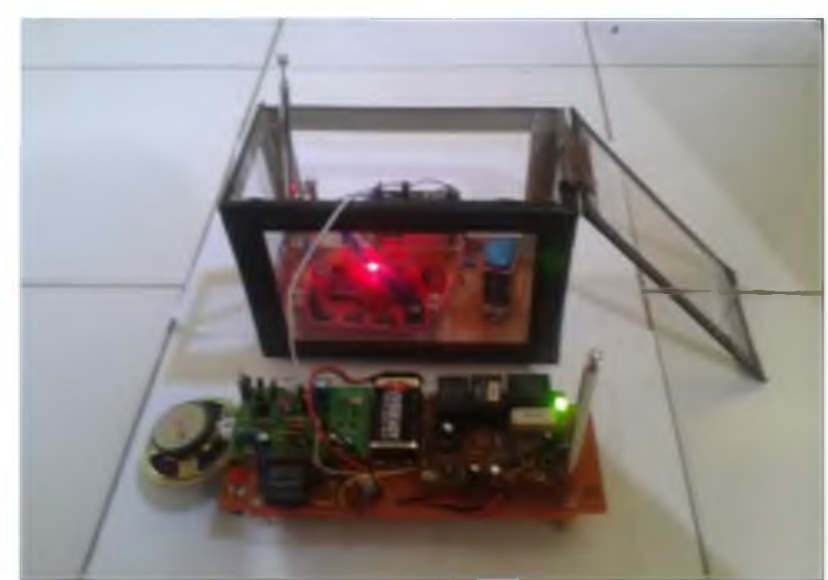

Gambar 5. Rangkaian sirine dan mikrokontroler transceiver

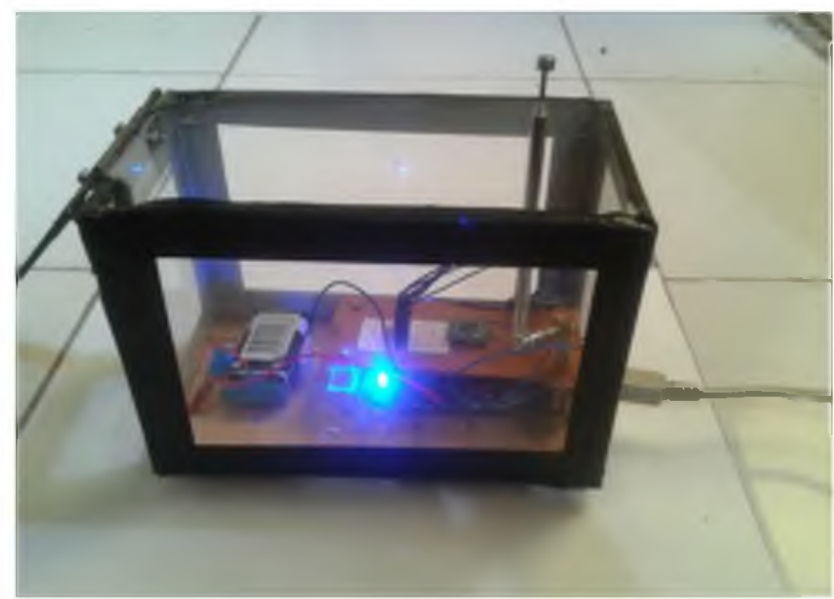

Gambar 6. Rangkaian mikrokontroler receiver 


\section{Ujicoba Software}

Software yang dibuat adalah aplikasi untuk video pemantauan serta untuk mengetahui adanya getaran yang ada di sekitar sensor getar. Sehingga menjadi acuan untuk menyimpan file video tersebut. Aplikasi terdiri dari, aplikasi server dan aplikasi client.

\section{Hasil Ujicoba dan Analisa}

Tabel 1 Hasil Pengamatan Rangkaian Sensor Getar

\begin{tabular}{|c|c|}
\hline Jarak & Keterangan \\
\hline 5 meter & Alarm bunyi dan dapat mengirim data ke aplikasi server \\
\hline $\begin{array}{c}30 \\
\text { meter }\end{array}$ & Alarm bunyi dan dapat mengirim data ke aplikasi server \\
\hline $\begin{array}{c}50 \\
\text { meter }\end{array}$ & $\begin{array}{c}\text { Alarm tidak bunyi dan tidak dapat mengirim data ke aplikasi } \\
\text { server }\end{array}$ \\
\hline
\end{tabular}

\section{Ujicoba Aplikasi Server}

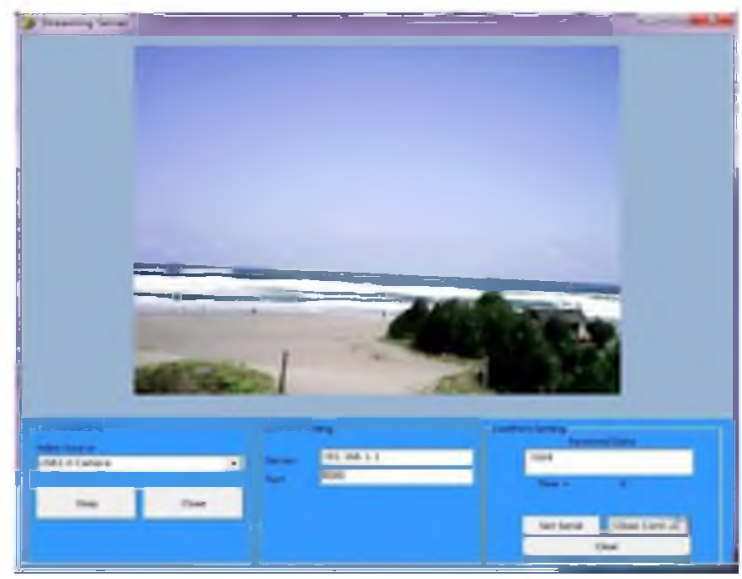

Gambar 7. Aplikasi server tidak mendeteksi adanya getaran.

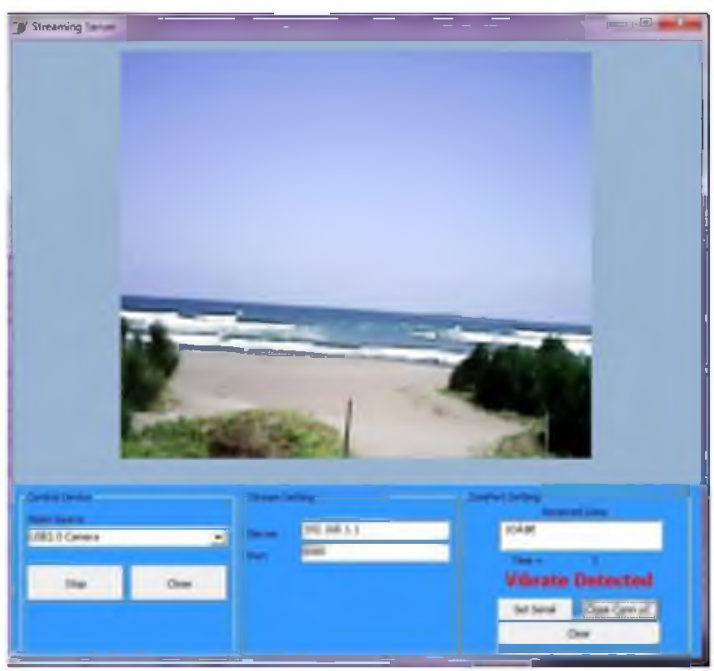

Gambar 8. Aplikasi server mendeteksi adanya getaran. 


\section{Ujicoba Pada Jaringan LAN Dalam Satu Network ID}

Tabel 2 Hasil Ujicoba Jaringan LAN Satu Network ID

\begin{tabular}{|l|c|c|c|c|l|}
\hline No & IP Client & IP Server & Port & Buffering & \multicolumn{1}{|c|}{ Keterangan } \\
\hline 1 & 192.168 .1 .2 & 192.168 .1 .1 & 8080 & Iya & $\begin{array}{l}\text { Streaming video berhasil } \\
\text { dengan waktu buffer } \\
\text { 10 detik }\end{array}$ \\
\hline 2 & 192.168 .1 .3 & 192.168 .1 .1 & 8080 & Iya & $\begin{array}{l}\text { Streaming video berhasil } \\
\text { dengan waktu buffer } \\
\text { 10 detik }\end{array}$ \\
\hline
\end{tabular}

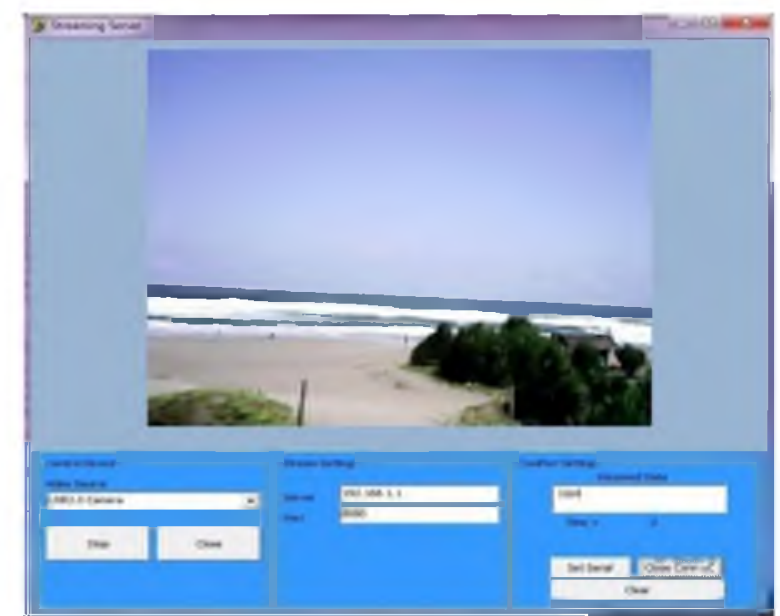

Gambar 9. Aplikasi Server pada Jaringan LAN Satu Network ID

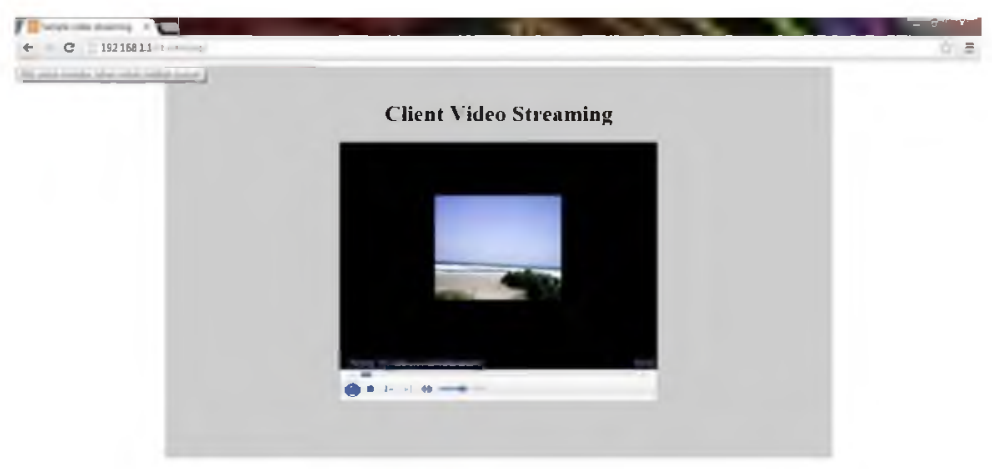

Gambar 10. Aplikasi Client pada Jaringan LAN Satu Network ID 


\section{Ujicoba Pada Jaringan LAN Yang Berbeda Network ID}

Tabel 3 Hasil Ujicoba Jaringan LAN Berbeda Network ID

\begin{tabular}{|c|c|c|c|c|c|}
\hline No & IP Client & IP Server & Port & Buffering & Keterangan \\
\hline 1 & 10.10 .10 .5 & 192.168 .6 .45 & 8080 & Iya & $\begin{array}{l}\text { Streaming video } \\
\text { berhasil dengan } \\
\text { waktu buffer 25detik }\end{array}$ \\
\hline 2 & 192.168 .10 .2 & 192.168 .6 .45 & 8080 & Iya & $\begin{array}{c}\text { Streaming video } \\
\text { berhasil dengan } \\
\text { waktu buffer 18 } \\
\text { detik }\end{array}$ \\
\hline 3 & 192.168 .6 .46 & 192.168 .6 .45 & 8080 & Iya & $\begin{array}{c}\text { Streaming video } \\
\text { berhasil dengan } \\
\text { waktu buffer 10 } \\
\text { detik }\end{array}$ \\
\hline
\end{tabular}

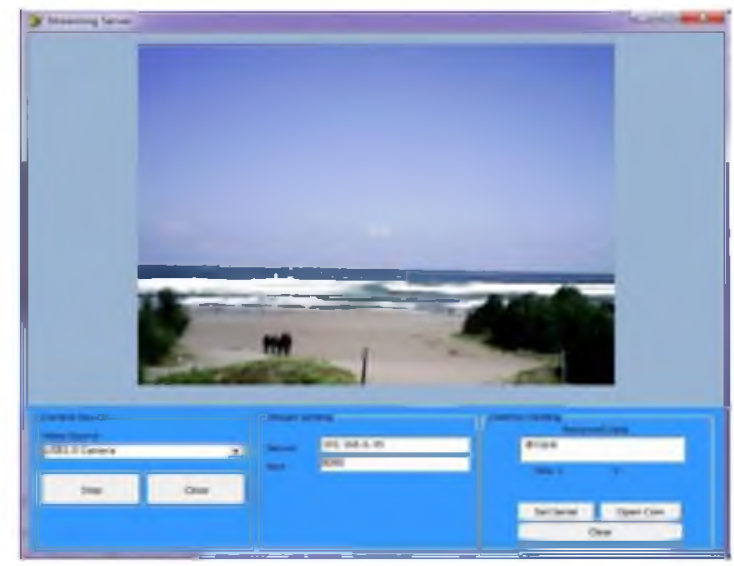

Gambar 11. Aplikasi Server pada Jaringan LAN Berbeda Network ID

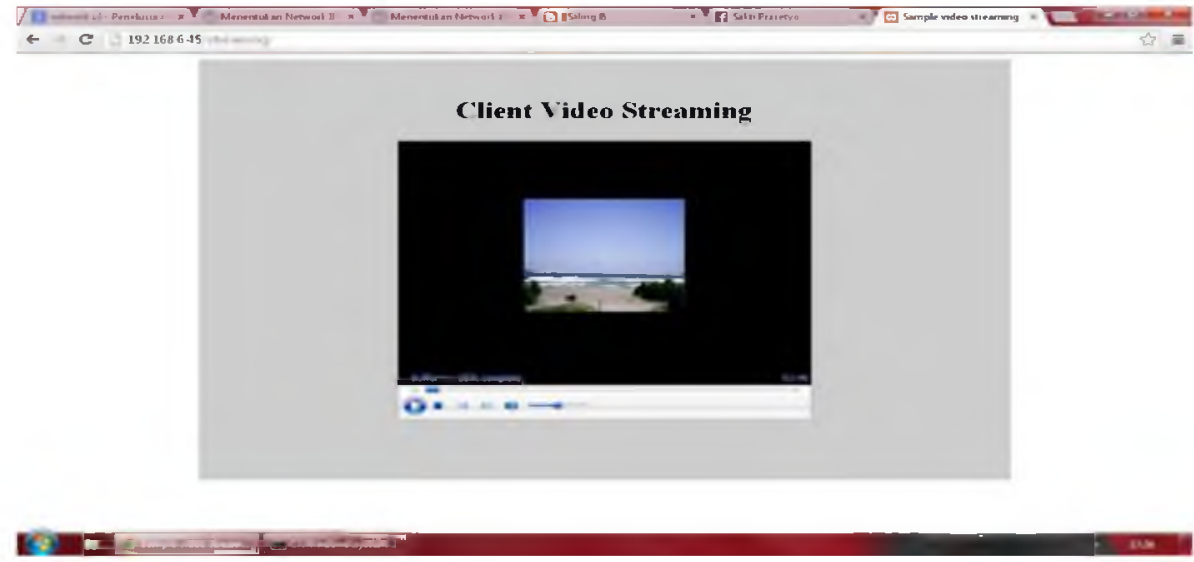

Gambar 12. Aplikasi Client pada Jaringan LAN Berbeda Network ID 


\section{Ujicoba Pada Jaringan Internet}

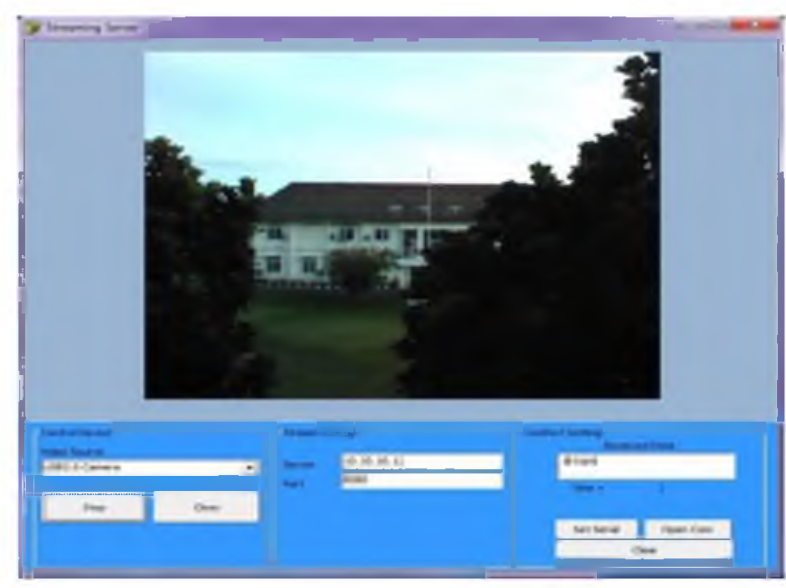

Gambar 13. Aplikasi Server pada Jaringan Internet

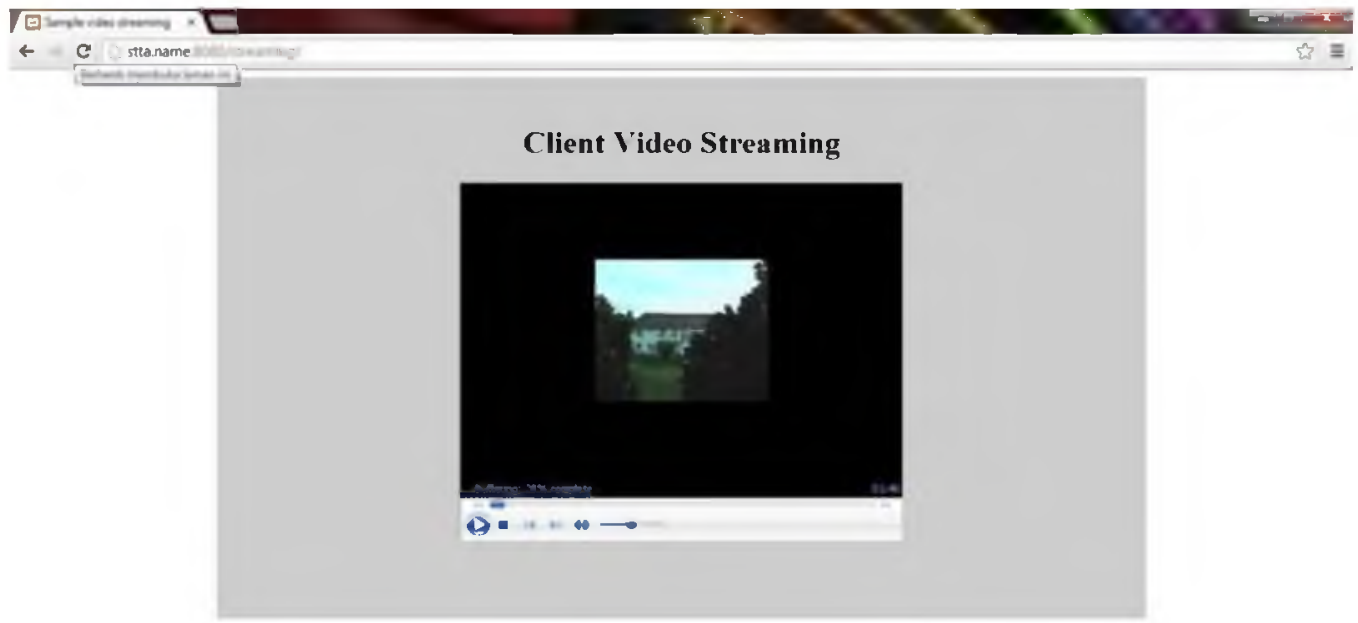

Gambar 14. Aplikasi Client pada Jaringan Internet

Berdasarkan hasil ujicoba pada jaringan internet dapat diketahui bahwa aplikasi client membutuhkan buffer yang sangat lama. Karena aplikasi server dan aplikasi client membutuhkan bandwidth yang besar untuk memproses streaming dari video tersebut.

Analisa dari hasil percobaan adalah sebagai berikut:

1. Sensor getar dapat berfungsi dengan baik pada jarak sekitar 30 meter untuk membunyikan sirine dan mingirim sinyal ke mikrokontroler.

2. Aplikasi server dapat menerima data dari rangkaian sensor getar dan mikrokontroler sebagai acuan untuk penyimpanan file video.

3. Aplikasi client dapat menerima informasi atau meangakses video streaming dengan menggunakan port yang telah ditentukan oleh aplikasi server.

4. Dengan menggunakan jaringan LAN, semakin banyak komputer client mengakses alamat server, maka akan mempengaruhi kecepatan proses buffering pada web client.

5. Kelancaran buffering pada jaringan internet dipengaruhi oleh bandwidth yang ada pada komputer server dan bandwidth yang diperoleh komputer client. 


\section{Kesimpulan Dan Saran}

\section{KESIMPULAN}

1. Sistem alarm sebagai peringatan terjadinya gempa, mampu bekerja dengan baik karena mampu mengaktifkan sirine dan memberi data ke aplikasi sebagai acuan penyimpanan file hasil video pemantuan.

2. Proses streaming video bisa berjalan dengan baik pada jaringan LAN menggunakan protokol HTTP 8080.

3. Masyarakat sebagai client dapat mengakses hasil video streaming melalui alamat server yang telah ditentukan oleh aplikasi server.

\section{SARAN}

1. Pada implementasi pada jaringan internet diperlukan bandwidth yang sangat besar karena file yang dikirimkan berupa video.

2. Mengembangkan alat pada media transmisinya untuk menambah daya jangkauannya.

3. Penggunaan webcam standart dapat diganti dengan menggunakan IP CAM atau RF CAM untuk meminimalkan keterbatasan alat dalam hal panjang kabel transmisi data.

\section{Daftar Pustaka}

Ahmad Balza, 2011. Pemrograman Delphi untuk Aplikasi Mesin Visi Menggunakan Webcam. Graha Media : Yogyakarta.

Charibaldi Novrido, Dessyanto Boedi Prasetyo, Jatu Wiedyasari, 2009. Aplikasi Kamera Video untuk Pemantau Keadaan Suatu Ruangan. Prosiding ISSN 1979-2328. Seminar Nasional Informatika 2009. UPN Veteran Yogyakarta : Yogyakarta.

Fadlisyah Rizal, 2011. Pemrograman Computer Vision pada Video Menggunakan Delphi + Vision Lab VCL 4.0.1. Graha Ilmu : Yogyakarta.

Sukriansyah Edi, Hubbul Walidainy, Nasaruddin, 2012. Sistem Monitoring dan Informasi Peringatan Tsunami Berbasis Wireless UHF Camera dan Wireless IP Camera. Prosiding ISSN 2088-9984. Seminar Nasional dan Ekspo Teknik Elektro 2012 : Medan.

Syafrizal Melwin, 2005. Pengantar Jaringan Komputer. Andi Offset: Yogyakarta.

\section{Daftar Pustaka Internet}

http://vwlowen.co.uk/directshow/asfuriter/page01.html, diakses pada tanggal 27 Desember 2012.

http://aman-auliarahman.blogspot.com/2012/10/tutorial - cara - pemula - belajar program.html, diakses pada tanggal 23 Maret 2013.

http://daneytech.com. E-book : Kurniawan Dayat, 2011. Mahir Pemrograman Webcam dengan Delphi, diakses pada tanggal 26 April 2013.

http://www.digi-zoare.com, diakses pada tanggal 11 Desember 2012.

http://www.klinik-robot.com, diakses pada tanggal 20 Desember 2012. 
Wahyu Irawan, Denny Dermawan, Nurcahyani Dewi

http://www.mercubuana.ac.id/file/jurnal\%20murdifin.pdf diakses pada tanggal 21 Juli 2013. 